\title{
Examining the Evidence of the Feminization of Poverty in Botswana
}

\author{
Khaufelo Raymond Lekobane, Keneilwe S. Mooketsane \\ Botswana Institute for Development Policy Analysis (BIDPA), University of Botswana \\ rlekobane@bidpa.bw
}

\begin{abstract}
Poverty in Botswana is more pronounced in female-headed households (FHHs) especially those residing in rural areas where employment opportunities are limited. Similarly, the proportion of the FHHs to the total poor increased between 2002/03 and 2009/10. However, no study has so far analyzed whether feminization of poverty has occurred. This paper therefore, examines feminization of poverty in Botswana using the 2009/10 Botswana Core Welfare Indicator Survey and the 2002/03 Household Income and Expenditure Survey datasets. The results indicate no evidence of feminization of poverty (at both national and regional levels). However, the results reveal evidence of feminization of poverty amongst the married couples, the widowed, the divorced, the unemployed, those working in own farms and the self-employed. Therefore, public policy should focus on gender sensitive poverty alleviation strategies, with specific focus on the vulnerable FHHs, especially the divorced/separated and the widowed, in order to fully address the feminization of poverty amongst these groups.
\end{abstract}

Keywords: Botswana; feminization of poverty; female headed households

\section{Introduction}

The concept of feminization of poverty was first introduced by Diana Pearce in the early 1970s, when it was discovered that FHHs in the United States were growing at an alarming rate (Pearce, 1978). Feminization of poverty may be defined as a situation where women, especially FHHs, are concentrated amongst the poor. It may manifest as: (1) an increase of women amongst the poor or (2) an increase of FHHs amongst the poor households (Pearce, 1978). Some studies have modified these concepts to try and capture the changes in poverty differentials amongst men and women or FHHs and MHHs over time. For example, Northrop (1990), Pressman (1988) and Peterson (1987) defined feminization of poverty as an increase in the differential poverty between FHHs and MHHs while Wright (1992) and Fuchs (1986) defined feminization of poverty as an increase in the differential poverty between women and men. Moreover, in cases where poverty rates for both FHHs and MHHs have both declined over time and the decline was lower amongst women, it can be concluded that there has been feminization of poverty (Medeiros \& Costa, 2008). These definitions capture changes in differential poverty over time, and recognize feminization of poverty as a process instead of a state.

Since its introduction, this concept has been widely investigated by both scholars and researchers (Aggrawal, 2012; Brady \& Kall, 2008; Medeiros \& Costa, 2008; Thibos et al., 2007; Moghadam, 2005; Chant, 2003; 1997; Fuwa, 2000; Bianch, 1999; Buvinic \& Gupta, 1997; Wright, 1992; Northrop, 1990; Fuchs, 1986; Pressman, 1988; Peterson, 1987). While evidence has been mixed, some of these studies have found that "women have consistently constituted a larger proportion of the poor population than men" (Thibos et al., 2007, pp.1), and that women have accounted for a larger proportion of the growing percentage of the world's poor (Buvinic \& Gupta, 1997). According to UNICEF (2007), of the 1.5 billion people living in absolute poverty (earning less than a dollar per day), about 70 percent are women. In the USA, for example, researchers found mixed results on whether feminization of poverty has occurred. Pearce (1978) found an increase of both women and FHHs members amongst the poor between the 1950s and the mid-1970s. Other researchers reached the same conclusion for the early 1960s (Northrop, 1990; Goldberg \& Kremen, 1990; Pressman, 1988; Peterson, 1987; Fuchs, 1986). However, Fuchs (1986) found no evidence of feminization of poverty in the USA after 1970, whereas Goldberg and Kremen (1990) and Peterson (1987) maintained that there was a feminization of poverty during the same period. Davies and Joshi (1998) and Wright (1992) found no evidence of feminization of poverty in the United Kingdom. Elsewhere, Dooley (1994) found evidence of feminization of 
poverty in 1973 and 1990 in Canada. However, Medeiros and Costa (2008) found no clear evidence of feminization of poverty in Latin America.

Aggarwal (2012) concluded that one of the major factors attributed to a greater burden of women's poverty is the increase in the number of FHHs. In both developed and developing countries, there has been an increase in the number of FHHs (Todaro, 1989). Pearce (1978) found that in the late 1970s the fastest growing family structure in the United States was that of FHHs and that there was an increase of both women and FHHs members amongst the poor between the 1950s and the mid-1070s. Subsequently, it was believed that about half of the poor in the United States lived in FHHs in the mid-1980s (Moghadam, 2005). Similarly, some studies have also claimed that the growing poverty in sub-Saharan Africa is associated with the rise in the number of FHHs and that such households are disproportionately poor (Buvinic \& Gupta, 1997). Additionally, a comparison of 61 studies concluded that 38 of them showed an over-representation of FHHs amongst the poor in sub-Saharan Africa (Buvinic \& Gupta, 1997). The occurrence of feminization of poverty in the world has also been widely acknowledged amongst women advocates (Medeiros \& Costa, 2008). For example, the 1995 Beijing Platform for Action identified the eradication of the persistent and increasing burden of poverty on women as one of the critical areas of concern requiring special attention by the international community, governments and civil society (Medeiros \& Costa, 2008). Similarly, United Nations Commission on the Status of Women has prioritized the issue of women and poverty and has urged all the UN member states and the international community to mainstream gender perspectives in all their poverty eradication policies and programmes (UN, 1996; 2000; 2003). The objective of this paper is to examine evidence of feminization of poverty in Botswana using both the 2002/03 HIES and the 2009/10 BCWIS. The rest of the paper is organized as follows. Section 2 provides the background information of Botswana, while section 3 discusses the methodology and data. In section 4 , the paper presents and discusses the results. Section 5 concludes and provides policy implications.

\section{Background Information of Botswana}

Botswana has remarkably transcended from amongst the poorest countries in the world to a middle income country. The country has since independence in 1966, prospered and enjoyed economic growth and development as well as political stability. Over the years, Botswana has maintained Africa's top position in transparency and good governance indexes, and it is deemed a shining beacon of democracy on the continent. Despite such progress and accolades, Botswana has a high income inequality with the Gini index estimated at 0.645 in 2009/2010, placing the country amongst the most unequal in terms of disposable income (Statistics Botswana, 2013). According to the 2014 World Economic Forum report, Botswana ranked 51 out of the 142 countries, placing it higher than South Africa and Namibia (at position 17 and 44, respectively), with regard to the Global Gender Gap Index (GGI) (WEF, 2014) ${ }^{1}$. Similarly, according to the Gender Inequality Index (GII), Botswana ranked higher (position 100) than South Africa (position 99) and Namibia (position 87) out of 187 countries (UNDP, 2013) 2 .

Poverty in Botswana is more pronounced in female-headed households (FHHs), especially those residing in rural areas where employment opportunities are limited and is also higher amongst women in general (Statistics Botswana, 2013; Lekobane and Seleka, 2014). Although overall income poverty has been on the decline, the total share of the poor has been dominated by women. For example, FHHs accounted for about 54 percent of the total poor in 2002/03 and the figure had increased to about 60 percent by 2009/10 (CSO, 2008; Statistics Botswana, 2013). Moreover, the total decline in household poverty was higher (56.2 percent) for the male-headed households (MHHs) compared to FHHs (45.1 percent). The high incidences of poverty amongst women could be an indication that poverty alleviation programs are not effective in targeting the most vulnerable. It could also be an indication of the failure in the system to redistribute resources and opportunities fairly and equitably. One of the key contributing factors is that women constitute the majority of the unemployed, both in rural and urban Botswana. For example, in 2009/10, the female unemployment rate stood at 21.4 percent, compared to 14.6 percent for males (Statistics Botswana, 2013).

Poverty is a global challenge experienced in both developed and developing countries, and manifests itself in multiple ways. It has various dimensions and can be addressed variably. Due to socio-cultural and political issues in Botswana, women bear the brunt of poverty more than men for several reasons. For example, 
Botswana is said to have a society and a legal system which are highly discriminatory to women (Scribner \& Lambert, 2010). Furthermore, Botswana has been defined as a highly patriarchal society, and Tswana culture tends to disadvantage women over men. Within customary marriages, property remains subject to the husband's control as head of the family (Mogwe, 2013). The effects of historic inequalities experienced by women bear negative consequences on their current status. Historically and culturally entrenched inequalities in access to opportunities, resources and power are bound to trail progressive regulatory reforms; furthermore, it will take time for reforms to fully undo such inequalities (UN, 2010).

The government of Botswana equally acknowledges that "more remains to be done to advance the rights of women and girls and to reverse the deeply and long entrenched inequalities emanating from patriarchal systems and discriminatory cultural practices" (Gender Affairs Department, 2014, pp.10). Women in Botswana have limited access and control to productive resources. Ownership of land, boreholes and livestock (which are considered key assets in the Tswana community and culture) is skewed in favour of men (UN, 2010). The customary law gives more access and control of land to men. However, a precedent was set through the Mmusi and Others vs Ramantele case, where four women challenged the Ngwaketse customary law ruling which allowed for the youngest son to inherit the family home, stating that it infringed on their constitutional right to equality (Jonas, 2013). The High Court overturned the decision of the Customary Court, ruling in favour of the women.

Representation of women in Political decision making institutions such as parliament is poor and on the decline. The ratio of women in parliament declined from 18 percent in 1999 to 7 percent in 2009 (Mooketsane, 2014). Following the most recent 2014 national elections, representation of women in parliament has not improved and remains at 7 percent. The poor representation of women in parliament means that women are not well represented in a platform where key decisions affecting their lives are made. Equality, inclusion and participation of all groups in decision making and democratic governance are important tenants of a democracy. Despite the challenges, the country has made progress in some areas such as amendments of policies and laws which were discriminatory to women. The abolition of the Marital Power Act of 2004, which made wives minors to their husbands, was a progressive legal reform and an accomplishment in removing statutory subordination of women to men (MLHA, 2014). According to the 2010 Millennium Development Goals Report, Botswana has achieved parity in primary and secondary education and the share of women in decision-making positions in public and private sectors has grown (UN, 2010).

Government's establishment of the Gender Affairs Department in 2013 (replacing Women's Affairs Department), a department solely dedicated to gender issues, was another achievement in advancing the rights of women and empowering them. It is also an indication of commitment to the course of women, and to mainstream gender perspectives into laws, policies, development frameworks and program initiatives across sectors. The government of Botswana has prioritized poverty eradication as one of its key areas of focus (President Ian Khama's 2008 Inaugural Address, State of the nation address 2008), a shift from the previous poverty reduction stand. This was informed by the government's intention to surpass the Millennium Development Goal target of reducing extreme poverty by half in 2015 (Republic of Botswana, 2012). Consequently, there has been increased commitment and strong drive from the leadership in so far as poverty eradication is concerned. The designated poverty eradication programs are led and run from the Office of the President since they are a high priority to the government. Despite the greater incidence of poverty amongst women in Botswana, poverty is still not sufficiently analyzed through a gender lens. Moreover, no study has so far analyzed whether feminization of poverty has occurred in Botswana.

\section{Methodology and Data}

Our study is limited to the monetary dimension of poverty. Therefore, in examining evidence of feminization, we are referring to the monetary dimension of poverty; in this case, the consumption approach. However, this study acknowledges that poverty is multidimensional and that consumption (or income) is just one of the deprivations of poverty. We adopted the definition of feminization of poverty as proposed by Medeiros and Costa (2008). They defined feminization of poverty as "an increase in levels of poverty amongst women or FHHs relative to the levels amongst men or MHHs" (pp.120). This can be measured using either ratios or differences. The poverty incidences are already in ratios (headcount ratios) based on the Foster, Greer and 
Thorbecke (1984) measure of poverty ${ }^{3}$. We therefore use differences in this paper as they are more appropriate than ratios. The use of ratios may lead to misleading interpretations, especially in cases where small percentage differences lead to large ratio differences, which may lead to conclusions that feminizations may have occurred when in actual fact it has not. Therefore, the use of ratios is not appropriate for a study such as this. This definition can be split into two; (1) an increase in the difference in levels of poverty amongst women and amongst men; and (2) an increase in the difference in levels of poverty amongst FHHs and amongst MHHs. This paper adopts the second definition and therefore examines feminization of poverty at household level. In line with the adopted definition, feminization of poverty occurs if the following condition prevails:

$$
P_{\alpha t}\left(f_{h}\right)-P_{\alpha t}\left(m_{h}\right)<P_{\alpha t}{ }^{\prime}\left(f_{h}\right)-P_{\alpha t^{\prime}}\left(m_{h}\right)
$$

Where $P_{\alpha}$ stands for the Foster, Greer and Thorbecke (1984) measure of poverty (FGT), $t$ and $t^{\prime}$ for the initial and final points in time (that is, $t<t^{\prime}$ ), $f h$ for FHHs and mh for MHHs. Since FHHs are not homogeneous, we further examined feminization of poverty across regional dimensions (rural areas, urban villages and cities/towns) to capture the regional differences, and based on marital and employments status.

Data were obtained from the 2009/10 BCWIS and the 2002/03 HIES datasets. The BCWIS collected information from 7,732 households whilst the HIES collected information from 6,053 households, both conducted at national level, covering all the administrative districts (CSO, 2008; Statistics Botswana, 2013). Each survey covered household in rural, urban villages and cities/towns. The poverty datum lines (PDLs) calculated in the datasets use the cost of basic needs approach (CSO, 2008; Statistics Botswana, 2013). A household whose consumption expenditure was below the specified PDL was categorized as poor while that whose consumption expenditure was higher than its poverty line was classified as non-poor (CSO, 2008; Statistics Botswana, 2013). Descriptive statistics are presented in Annex Tables 1 and 2. The tables give the distribution of household heads by regional dimensions, marital status and employment status for both 2002/03 and 2009/10, based on the weighted and unweighted samples. Generally, the descriptive results are comparable for both the weighted and unweighted samples. It should however, be noted that the results of the analysis in this paper are based on the weighted sample.

\section{Results and Discussion}

Table 1 reports the findings at both national and regional (cities/towns, urban villages and rural areas) levels. As indicated therein, there is no evidence of feminization of poverty at both national and regional levels. The absence of feminization of poverty at both national and regional levels could be attributed to a mature and complex social protection system put forward by the government of Botswana which include amongst others the social assistance programs targeted to the most vulnerable groups in the country (World Bank and BIDPA, 2013). The government of Botswana has specified poverty eradication as one of its key areas of focus, a shift from the previous poverty reduction stand. Some of the programs geared at achieving this objective include a public works program (Ipelegeng) introduced and made permanent in 2009 as an instrument of poverty alleviation both in urban and rural areas (World Bank and BIDPA, 2013). Since its inception, the number of beneficiaries has increased steadily over time and females accounted to more than 70 percent of the total enrolment (BIDPA, 2012). Therefore, the absence of feminization of poverty between 2002/03 and 2009/10 could be partly attributed to programmes such as Ipelegeng, which enrols more women than men. Another social assistance programme, the Livestock Management and Infrastructure Development (LIMID), was introduced in 2007 with poverty alleviation component providing support for guinea fowl, Tswana chicken and small stock (sheep and goats) production to resource poor households, the majority of which are females (TRANSTEC and BIDPA, 2009). This may have contributed to the absence of feminization of poverty at both national and regional levels. However, in-depth studies would be required to verify if indeed the absence of feminization of poverty is related to some of the existing social assistance programmes. 
Table 1: Feminization of poverty across regions

\begin{tabular}{lcccccc}
\hline & $\mathbf{2 0 0 2 / 0 3}$ & \multicolumn{5}{c}{$\mathbf{2 0 0 9 / 1 0}$} \\
\cline { 2 - 7 } & $P_{t}\left(f_{h}\right)$ & $P_{t}\left(m_{h}\right)$ & $P_{t}\left(f_{h}\right)-P_{t}\left(m_{h}\right)$ & $P_{t^{\prime}}\left(f_{h}\right)$ & $P_{t^{\prime}}\left(m_{h}\right)$ & $P_{t^{\prime}}\left(f_{h}\right)-P_{t^{\prime}}\left(m_{h}\right)$ \\
\hline Cities/towns & 10.1 & 7.4 & 2.6 & 6.4 & 4.4 & 2.0 \\
Urban villages & 21.4 & 12.8 & 8.6 & 13.7 & 7.2 & 6.5 \\
Rural areas & 37.4 & 30.7 & 6.7 & 18.0 & 11.4 & 6.6 \\
National & 25.3 & 18.5 & 6.8 & 13.9 & 8.1 & 5.8 \\
\hline
\end{tabular}

Sources: Author Computed from CSO (2008) and Statistics Botswana (2013)

${ }^{*}$ feminization of poverty occurred $P_{t}\left(f_{h}\right)-P_{t}\left(m_{h}\right)<P_{t^{\prime}}\left(f_{h}\right)-P_{t^{\prime}}\left(m_{h}\right)$

An examination of feminization of poverty by marital status depicts an interesting pattern in poverty differentials between FHHs and MHHs (Table 2). The results show no evidence of feminization of poverty amongst households headed by cohabiting couples and those whose heads never married. However, the results show evidence of feminization of poverty amongst households headed by married couples, divorced/separated and the widowed, between 2002/03 and 2009/10. Feminization of poverty across the married heads was unexpected since the incidence of poverty was lower amongst FHHs in both periods compared to MHHs. However, the total decline in incidences of poverty was slower amongst FHHs than MHHs. The incidence of poverty amongst FHHs (married) declined by 8.6 percentage points while that for MHHs declined by 10.9 percentage points, resulting in feminization of poverty amongst the married couples. The evidence of feminization of poverty could also be attributed to the overall decline in the share of married couples from 30.6 percent in 2002/03 to 26.9 percent in 2009/10. The decline was higher among FHHs with 3.5 percentage points, compared to 2.2 percentage points for MHHs (see Table A1).

Evidence of feminization of poverty amongst the divorced/separated household heads could be attributed to the increase of the FHHs amongst the poor divorced/separated heads. Data show that, in 2002/03, FHHs account for about 67 percent of the poor households headed by the divorced/separated individuals, and the figure had increased to about 86.4 percent in 2009/10 (Statistics Botswana, 2013; CSO, 2008). Data also show an increase in the share of FHHs amongst the divorced/separated household heads living with children, from 77.0 percent in 2002/03 to 91.3 percent in 2009/10, an indication that evidence of feminization of poverty amongst the divorced/separated could also be related to the high dependency ratios amongst such households. This is expected since in most cases, when marriages dissolve either through divorce or separation, mothers usually have the custody of the children, and end up caring for their children alone resulting in increased vulnerability or likelihood of falling into or remaining in poverty. Evidence of feminization of poverty amongst the widowed could result from the increase in the share of FHHs amongst the total poor households headed by the widowed. The share of FHHs amongst the widowed increased from about 88.9 to 94.2 percent between 2002/03 and 2009/10. Similarly, the share of FHHs amongst households headed by the widowed heads living with children increased from 76.1 to 87.3 percent between 2002/03 and $2009 / 10$. Another reason could be that, in cases of the widowed, the departed partner could have been the breadwinner and thus resulted in loss of income for such households resulting in increased vulnerability to poverty over some time.

Table 2: Feminization of poverty across marital status

\begin{tabular}{lcccccc}
\hline & $\mathbf{2 0 0 2 / 0 3}$ & \multicolumn{5}{c}{$\mathbf{2 0 0 9 / 1 0}$} \\
\cline { 2 - 7 } & $P_{t}\left(f_{h}\right)$ & $P_{t}\left(m_{h}\right)$ & $P_{t}\left(f_{h}\right)-P_{t}\left(m_{h}\right)$ & $P_{t^{\prime}}\left(f_{h}\right)$ & $P_{t^{\prime}}\left(m_{h}\right)$ & $P_{t^{\prime}}\left(f_{h}\right)-P_{t^{\prime}}\left(m_{h}\right)$ \\
\hline Married* & 18.9 & 21.5 & -2.6 & 10.3 & 10.6 & -0.3 \\
Living Together & 25.1 & 20.2 & 5.0 & 13.3 & 9.9 & 3.4 \\
Divorced/Separated* & 24.8 & 17.8 & 7.0 & 13.5 & 4.2 & 9.3 \\
Widowed* & 34.7 & 28.5 & 6.2 & 15.6 & 5.4 & 10.2 \\
Never married & 22.8 & 11.5 & 11.3 & 14.2 & 3.8 & 10.4 \\
\hline
\end{tabular}

Sources: Author Computed from CSO (2008) and Statistics Botswana (2013)

"feminization of poverty occurred $P_{t}\left(f_{h}\right)-P_{t}\left(m_{h}\right)<P_{t^{\prime}}\left(f_{h}\right)-P_{t^{\prime}}\left(m_{h}\right)$

Table 3 reports feminization of poverty across employment status. The results show no evidence of feminization of poverty amongst households heads engaged in paid employment and amongst those working 
as unpaid family helpers. However, feminization of poverty occurred amongst the self-employed, the unemployed and those working in own land/ cattle post. Across the self-employed, the incidence of poverty for FHHs declined by 7.1 percentage points compared to 10.4 percentage points amongst MHHs, implying that the decline in the incidences of poverty was lower among FHHs. Similarly, the incidence of poverty for FHHs declined by 17.5 percentage points while that for MHHs declined by 21.4 percentage points and across those working in own land/cattle post. The share of FHHs among household heads working in own land/cattle post increased from 4.8 percent in 2002/03 to 8.3 percent in 2009/10 whilst that for MHHs declined from 12.9 to 10.2 percent during the same period; hence evidence of feminization of poverty (see Table A1).

Table 3: Feminization of poverty across employment status

\begin{tabular}{lcccccc}
\hline & $\mathbf{2 0 0 2 / 0 3}$ & \multicolumn{5}{c}{$\mathbf{2 0 0 9 / 1 0}$} \\
\cline { 2 - 7 } & $P_{t}\left(f_{h}\right)$ & $P_{t}\left(m_{h}\right)$ & $P_{t}\left(f_{h}\right)-P_{t}\left(m_{h}\right)$ & $P_{t^{\prime}}\left(f_{h}\right)$ & $P_{t^{\prime}}\left(m_{h}\right)$ & $P_{t^{\prime}}\left(f_{h}\right)-P_{t^{\prime}}\left(m_{h}\right)$ \\
\hline Paid employment & 11.9 & 8.7 & 3.2 & 7.2 & 5.3 & 1.9 \\
Self-employment* & 23.0 & 14.2 & 8.8 & 15.9 & 3.8 & 12.0 \\
Unpaid family helper & 38.7 & 14.0 & 24.7 & 24.2 & 9.2 & 15.1 \\
Own land/cattle post* & 32.4 & 37.3 & -4.9 & 17.6 & 12.1 & 5.5 \\
Unemployed* & 36.8 & 37.7 & -0.9 & 19.3 & 16.3 & 3.0 \\
\hline
\end{tabular}

Sources: Author Computed from CSO (2008) and Statistics Botswana (2013)

${ }^{*}$ feminization of poverty occurred $P_{t}\left(f_{h}\right)-P_{t}\left(m_{h}\right)<P_{t}\left(f_{h}\right)-P_{t}{ }^{\prime}\left(m_{h}\right)$

\section{Conclusion and Policy Implications}

The concept of feminization of poverty has been widely investigated by both scholars and researchers in both developed and developing countries. The majority of these studies concluded that women have consistently constituted a larger proportion of the poor population than men and women accounted for a larger proportion of the growing percentage of the world's poor. Similarly, in Botswana, poverty is more pronounced in FHHs than MHHs, especially in rural areas where employment opportunities are limited. Women and FHHs account for a larger proportion of the poor and the share has increased over time, suggesting that feminization of poverty may have occurred. However, no study has analyzed evidence of feminization of poverty in Botswana, and this constitutes the first attempt at investigating the subject in the country. We define feminization of poverty as the increase in the levels of poverty amongst FHHs relative to the levels for MHHs. Our study is limited to the monetary approach of poverty in measuring feminization of poverty. Therefore our conclusions refer mainly to the monetary dimension of poverty.

The results of the study indicate no evidence of feminization of poverty at both national and regional level. However, decomposing households by marital status reveals evidence of feminization of poverty amongst households headed by married couples, and divorced and widowed household heads. Therefore, public policy should focus on gender sensitive poverty alleviation strategies, with specific focus on the vulnerable FHHs, especially the divorced/separated and the widowed, in order to fully arrest feminization of poverty. This group accounted for about 12.5 percent of the total households in 2009/10 (translating to about 67,478 households) and also accounted for the larger share (80.7 percent) of the total divorced/separated or widowed household heads. Clearly these many households cannot be ignored and this paper recommends that a specific programme that targets such vulnerable households should be considered. Evidence of feminization of poverty was also observed amongst the unemployed, the self-employed and those working in own land/ cattle post. The majority of the unemployed comprised mainly of the female heads, accounting for more than 60 percent in both 2002/03 and 2009/10. The share of FHHs to households working in own land and cattle post also increased between the same period; from 24.4 to 40.7 percent.

\section{NOTES}

1. The GGI measures gender disparity based on four dimensions and gaps, namely, economic, political, education and health.

2. The GII measures gender disparity based on three dimensions; reproductive health, Empowerment and Labor market participation. 
3. The Foster, Greer and Thorbecke (1984) family of poverty measures is given by $P_{\alpha}=\frac{1}{n} \sum_{i=1}^{n}\left[\frac{Z_{i-} Y_{i}}{Z_{i}}\right]^{\alpha}$ where $\alpha \in\{0,1,2\}$ is a parameter of inequality, $\mathrm{Y}$ is consumption expenditure, and $\mathrm{n}$ is the number of households. When $\alpha=0$, we have the headcount ratio, which measures the share of the population below the poverty line Z. When $\alpha=1$, we get the poverty gap and when $\alpha=2$, get the squared poverty gap.

Acknowledgements: The authors would like to acknowledge the valuable comments from the anonymous reviewers. We would also like to express our gratitude to the Executive Director of BIDPA-Dr T.B. Seleka for his guidance and advice and the BIDPA staff for their comments in improving the manuscript.

\section{References}

Aggrawal, S. V. (2012). Female Headed Households and Feminization of Poverty. Research Journal of Social Sciences and Management, 2(4), 57-62.

Bianchi, S. M. (1999). Feminization and Juvenilization of Poverty: Trends, Relative Risks, Causes, and Consequences. Annual Review of Sociology, 2, 307-333.

Botswana Institute for Development Policy Analysis (BIDPA). (2010). Review of Ipelegeng Program. Gaborone: BIDPA.

Botswana Institute for Development Policy Analysis (BIDPA). (2010). Review of the National Strategy for Poverty Reduction: Social Protection for Poverty and Vulnerability Reduction. Gaborone: BIDPA.

Botswana Power Corporation. (2011). Gender Mainstreaming in the Botswana Power Corporation, Botswana Power Corporation.

Brady, D. \& Kall, D. (2008). Nearly universal, but somewhat distinct: The feminization of poverty in affluent Western Democracies, 1969-2000. Social Science Research, 37(3), 976-1007.

Buvinic, M. \& Gupta, G. R. (1997). Female headed household and female maintained females: are they worth targeting to reduce poverty in developing countries? Economic Development and Cultural Change, 45(2), 259-280.

Central Statistics Office. (2008). Poverty Datum Line for Botswana for 2003. Gaborone, Central Statistics Office.

Chant, S. (1997). Women headed households: poorest of the poor? Perspectives from Mexico, Costa Rica and the Philippines. IDS Bulletin, 28(3), 26-48.

Chant, S. (2003). Female household headship and the feminization of poverty: facts, fictions and forward strategies. New Working Paper Series, Issue, 9, London: LSE Gender Institute.

Davies, H. \& Joshi, H. (1998). Gender and income inequality in the UK 1968-1990: The feminization of earnings or of poverty? Journal of the Royal Statistics Society: Series A (Statistics-in-Society), 161(1).

Dooley, M. D. (1994). Women, children and poverty in Canada. Canadian Public Policy, 20(4), 430-443.

Foster, J., Greer, J. \& Thorbecke, E. (1984). A class of decomposable poverty measures. Econometrica, 52, 76165.

Fuchs, V. R. (1986). The feminization of poverty? Working paper No. 1934, National Bureau of Economic Research, Cambridge.

Fuwa, N. (2000). The Poverty and Heterogeneity among female-headed households revisited: The case of Panama. World Development, 28(8), 1515-1542.

Garfinkel, I., McLanahan, S. S. \& Robins, P. K. (1994). Child Support and Child Well-being. Washington DC: Urban Institute Press.

Goldberg, G. \& Kremen, E. (1990). The feminization of poverty. Only in America? New York: Praeger.

Jonas, 0. (2013). Gender Equality in Botswana: The case of Mmusi and others V Ramantele and others. African Human Rights Law Journal, 13, 229-244.

Lekobane, K. R. \& Seleka, T. B. (2014). Determinants of Household Welfare and Poverty in Botswana, 2002/03 and 2009/10. BIDPA Working Paper No. 38. Gaborone: Botswana Development Policy Analysis (BIDPA).

Lochhead, C. \& Scott, K. (2000). The dynamics of women in Canada. Canadian Council of Social Development.

Medeiros, M. \& Costa, J. (2008). Is there a feminization of poverty in Latin America? World Development, $36(1), 115-127$. 
Ministry of Labor and Home Affairs (MLHA). (2014). Botswana Country Report on the Implementation of the Beijing Platform of the Beijing Platform for Action (Beijing Plus20 years). Gaborone: Gender Affairs Department.

Moghadam, V. (2005). The 'feminization of poverty' and Women's human Sciences Papers in Women's studies/Gender Research No.2. UNESCO: Paris.

Mogwe, A. (2013). Customary Law and its Impact on Women's Rights, Childrens' Rights and Lesbians, Gays, Bisexuals, Transsexuals and Intersexed (LGBTI) People in Southern Africa: The Botswana Example. Paper No. 14/2013 Prepared for Friedrich-Naumann-Stiftung für die Freiheit (FNF) by DITSHWANELO- Botswana - The Centre for Human Rights. Gaborone: Botswana.

Mooketsane, K. S. (2014). Gender and Political Representation in Botswana. BIDPA Policy Brief No. 13. Gaborone: Botswana Institute for Development Policy Analysis (BIDPA).

Northrop, E. M. (1990). The feminization of poverty: The demographic factor and the composition of economic growth. Journal of Economic issues, 24(1), 145-160.

Pearce, D. (1978). The feminization of poverty: Women, Work and Welfare. Urban and Social Change Review, 11, 28-36.

Peterson, J. (1987). The feminization of poverty. Journal of Economic Issues, 21(1), 329-337.

Pressman, S. (1988). The feminization of poverty: Causes and Remedies. Challenge, 31(2), 57-61.

Republic of Botswana. (2012). Poverty Eradication Guidelines: Implementation of Packages. Gaborone: Republic of Botswana.

Scribner, D. \& Lambert, P. (2010). Constitutionalizing difference: A Case Study Analysis of Gender Provisions in Botswana and South Africa. Politics and gender, 6, 37-61.

Statistics Botswana. (2013). 2009/10 Botswana Core Welfare Indicator Survey Report. Gaborone, Statistics Botswana.

Thibos, M., Lavin-Loucks, D. \& Martin, M. (2007). The Feminization of Poverty. Dallas TX', The J. McDonald Williams Institute \& YWCA.

United Nations (UN). (1996). Resolutions Adopted by The General Assembly on the report of the Second Committee-Women in Development. Fiftieth session, General Assembly. New York: United Nations.

United Nations (UN). (2000). Resolutions Adopted by The General Assembly on the report of the Ad Hoc Committee of the Whole of the Twenty-third Special session of the General Assembly. New York: United Nations.

United Nations (UN). (2003). Resource Mobilization and Enabling Environment for poverty eradication in the context of the implementation of the Program of Action for the Least Developed Countries for the Decade 2000-2010. Commission on the Status of Women, Follow-up to Economic and Social Council resolutions and decisions- Note by Secretariat. New York: United Nations.

United Nations (UN). (2010). Botswana Millennium Development Goals Status Report. Gaborone, Botswana: United Nations.

United Nations International Children's Emergency Fund (UNICEF). (2007). Gender Equality-The Big Picture. New York: UNICEF.

World Bank and BIDPA. (2013). Botswana Social Protection Assessment. World Bank and BIDPA. Gaborone, Botswana.

Wright, R. E. (1992). A feminization of poverty in Great Britain? Review of Income and Wealth, 38(1), 17-25. 
Table A1: (Appendix 1): Descriptive Statistics based on the weighted sample

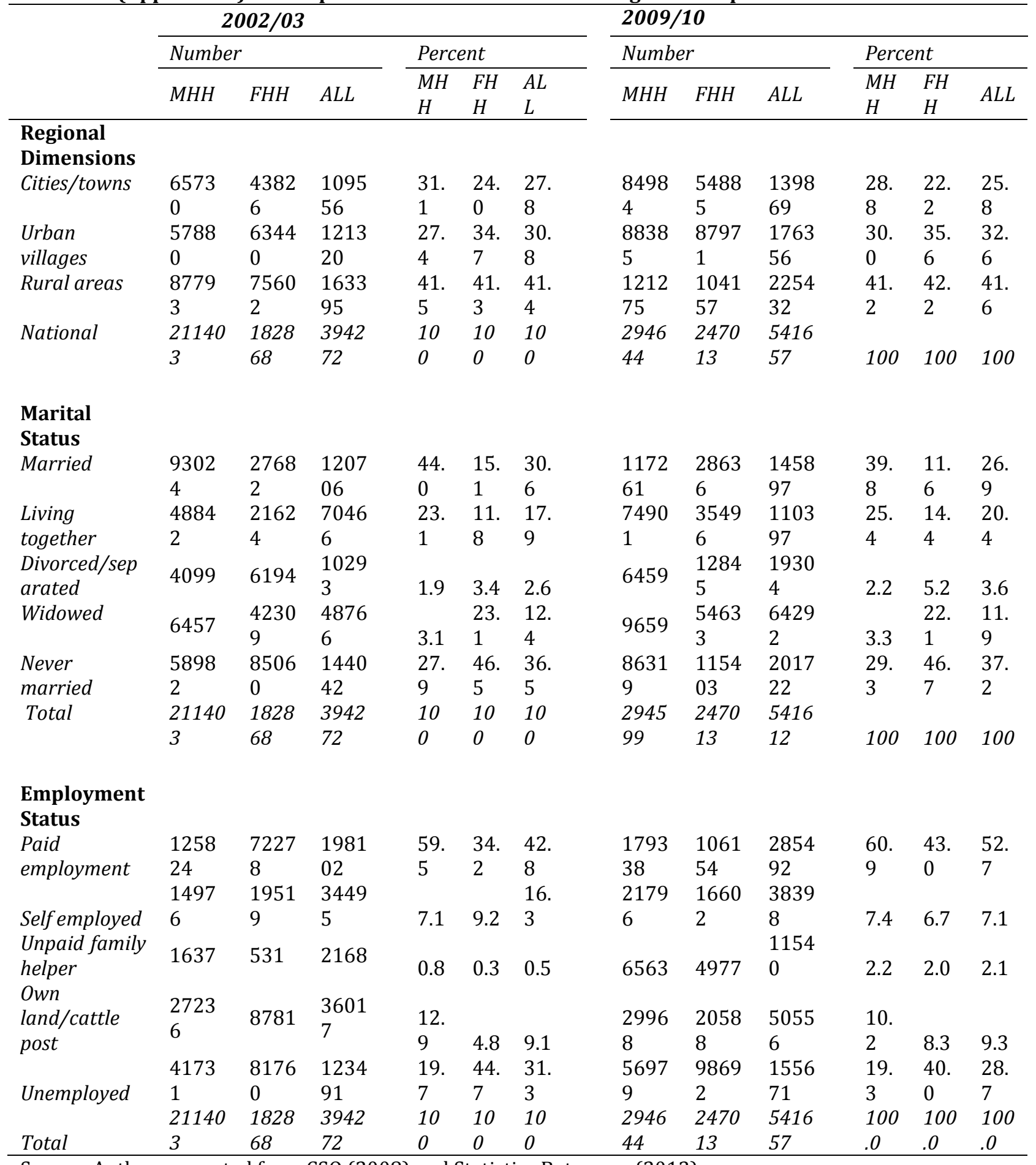

Source: Author computed from CSO (2008) and Statistics Botswana (2013) 
Table A2: (Appendix 2): Descriptive Statistics based on the unweighted sample

\begin{tabular}{|c|c|c|c|c|c|c|c|c|c|c|c|c|}
\hline & \multicolumn{6}{|c|}{$2002 / 03$} & \multicolumn{6}{|c|}{$2009 / 10$} \\
\hline & \multicolumn{3}{|c|}{ Number } & \multicolumn{3}{|c|}{ Percent } & \multicolumn{3}{|c|}{ Number } & \multicolumn{3}{|c|}{ Percent } \\
\hline & $\begin{array}{l}M H \\
H \\
\end{array}$ & FHH & $A L L$ & $\begin{array}{l}M H \\
H \\
\end{array}$ & $\begin{array}{l}F H \\
H \\
\end{array}$ & $A L L$ & $\begin{array}{l}M H \\
H \\
\end{array}$ & $F H H$ & $A L L$ & $\begin{array}{l}M H \\
H \\
\end{array}$ & $\begin{array}{l}F H \\
H \\
\end{array}$ & $A L L$ \\
\hline Cities/towns & 789 & 675 & $\begin{array}{l}146 \\
4\end{array}$ & 23.8 & $\begin{array}{l}24 . \\
6\end{array}$ & $\begin{array}{l}24 . \\
2\end{array}$ & $\begin{array}{l}125 \\
8\end{array}$ & 784 & $\begin{array}{l}204 \\
2\end{array}$ & 30.1 & $\begin{array}{l}22 . \\
1\end{array}$ & $\begin{array}{l}26 \\
4\end{array}$ \\
\hline Urban villages & 828 & 935 & $\begin{array}{l}176 \\
3\end{array}$ & 25.0 & $\begin{array}{l}34 . \\
1\end{array}$ & $\begin{array}{l}29 . \\
1\end{array}$ & $\begin{array}{l}118 \\
0\end{array}$ & $\begin{array}{l}125 \\
9\end{array}$ & $\begin{array}{l}243 \\
9\end{array}$ & 28.2 & $\begin{array}{l}35 . \\
4\end{array}$ & $\begin{array}{l}31 . \\
5\end{array}$ \\
\hline Rural areas & $\begin{array}{l}169 \\
6\end{array}$ & $\begin{array}{l}113 \\
0\end{array}$ & $\begin{array}{l}282 \\
6\end{array}$ & 51.2 & $\begin{array}{l}41 . \\
2\end{array}$ & $\begin{array}{l}46 . \\
7\end{array}$ & $\begin{array}{l}173 \\
9\end{array}$ & $\begin{array}{l}151 \\
2\end{array}$ & $\begin{array}{l}325 \\
1\end{array}$ & 41.6 & $\begin{array}{l}42 . \\
5\end{array}$ & $\begin{array}{l}42 . \\
0\end{array}$ \\
\hline Total & 3313 & $\begin{array}{l}274 \\
0\end{array}$ & $\begin{array}{l}605 \\
3\end{array}$ & 100 & 100 & 100 & $\begin{array}{l}417 \\
7\end{array}$ & $\begin{array}{l}355 \\
5\end{array}$ & $\begin{array}{l}773 \\
2\end{array}$ & 100 & 100 & 100 \\
\hline Married & $\begin{array}{l}145 \\
8\end{array}$ & 404 & $\begin{array}{l}186 \\
2\end{array}$ & 44.0 & $\begin{array}{l}14 . \\
7\end{array}$ & $\begin{array}{l}30 . \\
8\end{array}$ & $\begin{array}{l}167 \\
0\end{array}$ & 420 & $\begin{array}{l}209 \\
0\end{array}$ & 40.0 & $\begin{array}{l}11 . \\
8\end{array}$ & $\begin{array}{l}27 . \\
0\end{array}$ \\
\hline Living together & 764 & 346 & $\begin{array}{l}111 \\
0\end{array}$ & 23.1 & $\begin{array}{l}12 . \\
6\end{array}$ & $\begin{array}{l}18 . \\
3\end{array}$ & $\begin{array}{l}105 \\
4\end{array}$ & 503 & $\begin{array}{l}155 \\
7\end{array}$ & 25.2 & $\begin{array}{l}14 . \\
1\end{array}$ & $\begin{array}{l}20 . \\
1\end{array}$ \\
\hline $\begin{array}{l}\text { Divorced/separat } \\
\text { ed }\end{array}$ & 57 & 93 & 150 & 1.7 & 3.4 & 2.5 & 99 & 188 & 287 & 2.4 & 5.3 & 3.7 \\
\hline Widowed & 84 & 532 & 616 & 2.5 & $\begin{array}{l}19 . \\
4\end{array}$ & $\begin{array}{l}10 . \\
2\end{array}$ & 153 & 804 & 957 & 3.7 & $\begin{array}{l}22 \\
6\end{array}$ & $\begin{array}{l}12 . \\
4\end{array}$ \\
\hline Never married & 950 & $\begin{array}{l}136 \\
5\end{array}$ & $\begin{array}{l}231 \\
5\end{array}$ & 28.7 & $\begin{array}{l}49 . \\
8\end{array}$ & $\begin{array}{l}38 . \\
2\end{array}$ & $\begin{array}{l}120 \\
1\end{array}$ & $\begin{array}{l}164 \\
0\end{array}$ & $\begin{array}{l}284 \\
1\end{array}$ & 28.7 & $\begin{array}{l}46 . \\
1\end{array}$ & $\begin{array}{l}36 . \\
7\end{array}$ \\
\hline Total & 3313 & $\begin{array}{l}274 \\
0\end{array}$ & $\begin{array}{l}605 \\
3\end{array}$ & 100 & 100 & 100 & $\begin{array}{l}417 \\
7\end{array}$ & $\begin{array}{l}355 \\
5\end{array}$ & $\begin{array}{l}773 \\
2\end{array}$ & 100 & 100 & 100 \\
\hline & 221 & 129 & 350 & & 47. & 57. & 252 & 149 & 402 & & 42. & 52. \\
\hline Paid employment & 7 & 0 & 7 & 66.9 & 1 & 9 & 4 & 9 & 3 & 60.4 & 2 & 0 \\
\hline Self employed & 260 & 290 & 550 & 7.8 & $\begin{array}{l}10 . \\
6\end{array}$ & 9.1 & 315 & 238 & 553 & 7.5 & 6.7 & 7.2 \\
\hline $\begin{array}{l}\text { Unpaid family } \\
\text { helper }\end{array}$ & 17 & 6 & 23 & 0.5 & 0.2 & 0.4 & 89 & 71 & 160 & 2.1 & 2.0 & 2.1 \\
\hline $\begin{array}{l}\text { Own land/cattle } \\
\text { post }\end{array}$ & 268 & 82 & 350 & 8.1 & 3.0 & 5.8 & 436 & 311 & 747 & 10.4 & 8.7 & 9.7 \\
\hline Unemployed & 551 & $\begin{array}{l}107 \\
2\end{array}$ & $\begin{array}{l}162 \\
3\end{array}$ & 16.6 & $\begin{array}{l}39 . \\
1\end{array}$ & $\begin{array}{l}26 . \\
8\end{array}$ & 813 & $\begin{array}{l}143 \\
6\end{array}$ & $\begin{array}{l}224 \\
9\end{array}$ & 19.5 & $\begin{array}{l}40 . \\
4\end{array}$ & $\begin{array}{l}29 . \\
1\end{array}$ \\
\hline Total & 3313 & $\begin{array}{l}274 \\
0 \\
\end{array}$ & $\begin{array}{l}605 \\
3 \\
\end{array}$ & 100 & 100 & 100 & $\begin{array}{l}417 \\
7 \\
\end{array}$ & $\begin{array}{l}355 \\
5 \\
\end{array}$ & $\begin{array}{l}773 \\
2 \\
\end{array}$ & 100 & 100 & 100 \\
\hline
\end{tabular}

Source: Author computed from CSO (2008) and Statistics Botswana (2013) 